[Roberts, P., \& Peters, M. (1999). A Critique of the Tertiary Education White Paper. New Zealand Annual Review of Education, 8, 5-26]

\section{A Critique of the Tertiary Education White Paper}

\section{PETER RoBERTS AND MichaEl PETERS}

\section{Abstract:}

This article provides a critical commentary on key features of the long-awaited White Paper on tertiary education (Ministry of Education, 1998). Released in November 1998, the White Paper confirms many of the predictions made in earlier analyses of the Tertiary Education Review Green Paper (Ministry of Education, 1997a). The authors argue that despite claims to the contrary in the document, the White Paper is driven by a privatisation agenda, as evidenced by the favouring of new government subsidies for private training establishments, the decline in EFTS-based research support for public institutions, the introduction of new capital charges, and significant changes in the composition and nature of university Councils. Most worrying of all is the potential for undermining academic freedom and institutional autonomy with the granting of important new powers to the Minister of Education. The almost complete absence of any substantial discussion of information technology issues, identified as a major weakness of the Tertiary Education Review Green Paper, is repeated in the White Paper. The authors conclude that the White Paper represents one of the final steps in a process of incremental neoliberal reform, paving the way, via a far-reaching set of policy and legislative changes, to a fully privatised, consumer-driven tertiary education system. ${ }^{1}$

n November 1998 the long-awaited White Paper on Tertiary Education (Ministry of Education, 1998) was released by the New Zealand Government. The White Paper cements in place several crucial changes signalled in the leaked document of 1997 (Ministry of Education, 1997b), and confirms suspicions expressed in earlier articles ${ }^{2}$ about the way the Tertiary Education Review Green Paper (Ministry of Education, 1997a) would be interpreted by policy developers in the Ministry. It has already attracted a range of responses from the tertiary

\section{Peter Roberts and Michael Peters}

sector. The Association of University Staff of New Zealand (1998, p.1) has called it "inequitable, irresponsible, unworkable, and incoherent". Of the major political parties other than National, only ACT has supported the overall direction signalled in the document. Both Labour and the Alliance have been heavily critical, interpreting the White Paper as a serious threat to a credible public tertiary education system. The policy proposals have been enthusiastically embraced by the New Zealand Association of Private Education Providers, and there has also been (qualified) support from the New Zealand Business Roundtable. This article summarises some of the key features of the White Paper, offers brief critical comments on proposed changes, and identifies a number of important omissions in the document.

\section{An Overview}

In both substance and form the White Paper is not dissimilar to the Tertiary Education Review Green Paper. The level of detail in the discussion is, again, comparatively modest: the document comprises 56 pages of text, with a further 15 pages set aside for appendices. There are four major sections ("The Future Tertiary Environment", "The Process of the Review", "The Tertiary Review Package", "Implications for Maori") and a conclusion. The tertiary review "package" covers five key areas: subsidies and costs; quality assurance, protected terms, and financial viability; research; information; and governance and accountability. Significant legislative changes are signalled, and transitional arrangements during the period 1999-2001 are set out in one of the appendices.

The Minister of Education, Wyatt Creech, opens the White Paper with the following declaration:

A high-performing tertiary sector is a key to a forward-looking, cohesive, creative, and innovative society in the 21st century. Post-compulsory education and training is going to become more and more necessary to secure career paths and quality of life and to achieve an equitable, cohesive, and culturally dynamic society in which all members can fully participate. Employers will demand higher and more diverse skills and knowledge to support the creativity and enterprise upon which their success depends. Over the course of their lives, many people will face the need to retrain, upskill, and change direction - perhaps several times. (Creech, 1998, p. 2). 
The Minister acknowledges that rapid growth in the 1990s placed pressure on the tertiary education sector, and speaks of both substantial challenges facing the sector and the certainty of further change proceeding at the same pace. Seeking to "advance New Zealand's needs well into the future", the White Paper is, in the Minister's view, a forward-looking document concerned with meeting diverse and changing demands, and with upholding "quality education that meets international standards". Institutions, he asserts, will "need to adapt to meet the challenges and opportunities created by expanding frontiers of knowledge, the changing needs of students, and new learning technologies". The Minister claims that "[a] great deal of consultation has gone into the development of these proposals" and expresses the Government's hope that "a broad political consensus can be developed around tertiary reform". The White Paper, he says, "establishes ground rules for the successful future development of the tertiary education sector. It is up to us all to take advantage of the opportunities that the reforms create." (Creech, 1998, p. 2)

The first chapter of the White Paper provides an overview of the proposed changes and the rationale behind them. It begins with the now-familiar refrain about the importance of tertiary education for competitiveness, economic growth, employment, productivity, and social cohesion (Ministry of Education, 1998, p. 3). It is noted that in 1997 , over 214,000 students participated in public tertiary education courses, while 34,000 were enrolled in private training establishments. With 7 universities, 25 polytechnics, 4 colleges of education, 3 wananga, 11 government training establishments, and 700 private training establishments, the number of tertiary education institutions and organisations in New Zealand is, as the White Paper points out, very high for such a small country (p. 4). The small size of some of these institutions has cast doubt on their "long-term educational and financial viability", to which a number have responded with alliances and mergers of various kinds in an attempt to strengthen their positions (p. 4). The Ministry speaks of the need to improve accountability measures and systems of governance. The importance of maintaining the quality of tertiary education is stressed. This does not require the same quality assurance mechanism for all institutions: different approaches will be appropriate for different institutions. The Ministry expresses a commitment to protecting certain terms (including "university" and "degree") in order to prevent them "being devalued by misuse or abuse" (p. 8). Research, it is argued, should be "of high quality and relevant to the purpose for which it is carried out". It is claimed that the current legislative framework governing the tertiary sector is too prescriptive: "the sector would benefit from having clearer and more concise legislation that enables it to adapt to meet the inevitable changes that are necessary over time" (p. 13).

The major policy changes in the White Paper are set out in the third chapter, entitled "The Tertiary Review Package". In brief, these can be summarised as follows:

\section{Tuition and funding:}

1. A new Universal Tertiary Tuition Allowance (UTTA) will be available to subsidise costs for all domestic students enrolled in approved courses.

2. Students enrolled in courses taught in New Zealand by overseas organisations will also be able to claim the subsidy, provided the courses meet quality assurance criteria.

3. From the year 2000, private training establishments will receive the same subsidies as public institutions.

4. Base grants (currently $\$ 1000$ per EFTS, up to a maximum of $\$ 250,000$ per public tertiary institution) will be phased out after 1999 .

\section{Quality assurance:}

5. To receive consideration for government funding, "tertiary providers and qualifications developers will need to be quality assured through a recognised quality validation process" (p. 21).

6. In acknowledging the range of purposes served by different tertiary education institutions and organisations, a variety of approaches to quality validation will be allowed and encouraged.

7. A new overarching regulatory body, the Quality Assurance Authority, will be established to monitor quality validation processes. Recognised quality validation processes will those judged "sufficiently robust" by the Authority.

8. The New Zealand Qualifications Authority (NZQA) will be "repositioned" and renamed "Quality Validation Services". Its prime function will be to validate the quality of qualifications. Its other activities (including the development of unit standards) will be progressively transferred to other bodies.

\section{Protected terms:}

9. The use of the following terms will continue to be regulated: "university", "polytechnic", "college of education", "wananga" (for 
Tertiary Education Institutions), "degree" (including "bachelor", "master" and "doctorate"). The use of the terms "national" and "New Zealand" in describing qualifications will also be restricted.

\section{Financial viability:}

10. To be considered for government funding, "tertiary providers will need to demonstrate that they are solvent and are likely to remain so" (p. 27).

11. All institutions and organisations receiving government assistance will need to provide information on their policies for safeguarding "students' and educational interests" (p. 27).

\section{Research:}

12. From 2000, a new dual system for funding research will be introduced. A proportion (initially $80 \%$ ) of the government funding for research will be allocated through tuition subsidies based on student numbers; the rest (initially 20\%) will be allocated via a contestable pool. These proportions will, subject to a review to be carried out in 2001, have been reversed by 2002 (making $80 \%$ of research funding contestable).

\section{Tertiary education information:}

13. An electronic database of information relating to student enrolment, and a national register of "quality-assured" tertiary institutions, qualifications and courses will be established.

\section{Governance:}

14. Councils for Tertiary Education Institutions (including universities) will be reduced in size to 7-12 members.

15. TEIs will be required to negotiate with the Minister of Education in confirming membership of their Councils.

16. The Chair and majority of members of each Council must not be directly involved in the institution in any student or staff capacity. Only one student and one member of the institution's staff will be required on Councils.

17. The membership of Councils "will need to reflect the skills, knowledge and experience essential for effective governance of a tertiary institution. These include skills in business management, finance, and strategic planning, and knowledge of the education and research sectors" (pp. 38-39).

\section{Monitoring and accountability:}

18. In accordance with the Government's intention of moving progressively away from "central control of inputs" (p. 40) to an approach blending stronger accountability with greater institutional autonomy, TEIs will have to "prepare, and report against, an annual Statement of Intent outlining strategic direction and performance targets" (p. 39).

19. Restrictions on the use of assets will vary depending on the degree of "risk" (to the Crown) posed by an institution.

\section{Capital assets:}

20. "Asset rich" institutions will receive less funding through the UTTA than TEIs with fewer capital assets.

The fourth chapter of the White Paper details the Government's proposals for improving Maori participation in tertiary education. The Ministry of Education and Te Puni Kokiri have developed an "Education Strategy for Maori", the aim being to:

- establish a set of criteria and principles to evaluate policies to maximise the return to Maori ... ;

- enhance the influence of Maori over education policy by improving the accountability of providers and of the whole education system;

- improve the quality, capability, and diversity of schools and other education institutions;

- improve communications and provide information to the Maori community; and

- strengthen the links between Maori education policy and wider government social reform policies to ensure increasing success in education outcomes for Maori.

(pp. 44-46)

The White Paper suggests that the new resourcing system of "funding following the student" (vouchers) will, together with the policies on information and quality, improve prospects for Maori students. It is claimed that the new system of governance "could hold particular relevance to wananga, enabling them to develop further the distinctive characteristics of Maori tertiary education" (p. 48). It is noted, however, that the question of how wananga differ from other tertiary institutions is a complicated one. No firm commitment to resourcing the future growth of new wananga, beyond the UTTA available to all TEIs 
meeting quality assurance criteria, is made. Questions about capitalisation and finances for wananga are yet to be resolved, but are currently being considered by the Government.

The document closes with a concluding statement similar in tone to the introductory remarks. There is talk of the importance of a quality tertiary education system - one based on innovation, ideas and research - for "our success as a nation", for international competitiveness, for "our growth as individuals" and "the strength of our communities" (p. 55). The Government, it is said, will continue to play "a major role" in tertiary education. Because all approved tertiary education programmes rely on "a taxpayer subsidy", minimal barriers to innovation and growth need to be balanced with robust accountability mechanisms. The nature of the "student-provider relationship" is important in safeguarding taxpayers' investment in tertiary education. The proposals set out in the White Paper are designed to enable tertiary education institutions and organisations to adapt quickly to changing student demands while providing high quality courses and programmes.

Many of the changes in the White Paper had been expected; indeed, some had been signalled in budget statements made earlier in 1998. What was surprising for some commentators was just how far the government was prepared to go, both in extending its own powers and in making concessions to the private sector. We address this issue as a key element of our critique in the next section.

\section{A Critique}

\section{Privatisation}

The process of social policy reform provides a fascinating study in the dynamics of discourse, the art of political rhetoric and the exercising of political power. The White Paper attests to this in many respects but perhaps most vividly in relation to the question of privatisation. In the section entitled "The Process of the Review", the following comment on the 380 written submissions to the Tertiary Education Review Green Paper is made:

Submissions generally focused on the issues raised in the Green Paper, such as the importance of maintaining educational quality and improving accountability for the use of taxpayer funds. Some, however, focused on a mistaken belief that the Government intended to privatise tertiary education institutions (p. 14).
The White Paper does little to reassure those who hold this "mistaken" belief about privatisation. We see the proposals in the document as further steps in a process of incremental privatisation that has been under way for several years. The positive reaction to the White Paper from a range of private "providers" is hardly surprising: the public tertiary education system will, in effect, be subsidising private training establishments. As Jane Kelsey says, "why should taxpayers' money be channelled into private education when public education is severely stretched?" (1998, p. A19). On the face of it, such an appropriation of public money for aiding private purposes - where those purposes might include running for-profit "educational" enterprises from an off-shore location - seems bizarre. Such an approach makes sense, however, if the changes proposed in the White Paper are viewed as transitional arrangements in a larger privatisation agenda. If the intention is to systematically reduce government involvement in (and financial commitment to) tertiary education in New Zealand, incentives for the private sector assist in allowing a new competitive, customised environment to become established. This does not, however, need to be seen as planned strategy (or "grand conspiracy") for the point to hold. Rather, it is a matter of viewing changes in tertiary education in the light of trends, practices and ideological positions already firmly established in recent New Zealand history. Once the fundamental assumptions of market liberalism have been accepted, as they have by successive New Zealand governments from 1984, almost all major policy changes tend to follow a certain direction: the emphasis will always be on enhancing "choice", increasing competition, and (ostensibly) reducing government involvement in individual lives. Encouraging growth in private educational enterprises is simply another element in a larger neoliberal reform programme.

\section{Needs and Wants}

The proliferation of references to serving the "needs" of various groups - principally but not exclusively students - reaches new heights in the White Paper. Talk of meeting the "needs" of "consumers" is a regular feature of recent policy statements on tertiary education. In the case of the White Paper, however, this is sufficiently incessant to give the appearance of driving every major policy proposal. Statements about meeting ongoing, diverse and changing student "needs" can be found in Wyatt Creech's Foreword (Creech, 1998, p. 2), the first chapter (Ministry of Education, 1998, twice on p. 3, and on pp.12 \& 13), and the 
third chapter (p. 38). There are also references to the "needs" of the labour market (p. 24), different tertiary institutions (pp. 29 \& 37), the 21st century (p. 31), "stakeholders" (p. 38), and Maori (p. 52). The importance of using taxpayers' money effectively to meet (unspecified) "present and future needs" is also noted (p. 34). Such references to "needs", as we have argued elsewhere (Peters \& Roberts, 1999), are better understood as appeals to "wants" and demands. The use of the term "needs" is almost never supported by an account of what is necessary, as opposed to merely preferred, for the individual or groups being referred to. Moreover, little consideration is given to the ways in which "needs" are constructed, shaped, and modified; there is seldom any in-depth commentary on why and how "needs" might change. The consequences of changing preferences are never examined in detail. We believe the increase in the number of references to the term in the White Paper is more than coincidental: it corresponds with the shift further towards a fully consumer-driven system of tertiary education. In such a system, so-called "needs" - the demands of students, employers and the Government - are all that count in determining the distribution and use of resources. All decisions in tertiary institutions and organisations driven by these imperatives are ultimately based on the criterion of "giving the customer what he or she wants".

\section{New information technologies}

There are some significant omissions and silences in the White Paper, the most striking of which is the almost complete absence of any discussion about the new information technologies and the bearing they may have on tertiary education in New Zealand (in the immediate and long-term future). As far as concrete policy proposals go, there is a brief reference to electronic databases of information to assist with enrolment, but little else. The Minister of Education mentions the new learning technologies in his Foreword when referring to the "challenges and opportunities" facing the tertiary sector, yet there is virtually no elaboration on this in the body of the document. The need to "adapt to and exploit advances in information technology" is noted as a "key pressure" on the sector in the first chapter (p. 3), but it is not clear why this might be so, or how the pressure might be felt, or where it might be emerging from, or how tertiary institutions might respond to it. The Tertiary Education Review Green Paper has been criticised for its lack of attention to information technology issues (see, for example, Crozier, 1998; Peters \& Roberts, 1998a, 1998b). Considered against the background of Government rhetoric on the importance of innovation for national prosperity and well-being (e.g., Ministry of Research, Science and Technology, 1998), the omissions in the White Paper are all the more surprising. In the period following the release of the Green Paper, the Government has made a renewed commitment to the further development of learning technologies in educational institutions, but this is not reflected in the policy proposals set out in the White Paper.

\section{Governance}

The recommendations in the White Paper signal a decisive shift from collegial, democratic and representative systems of governance to a business model, with a significant reduction in the number of academic staff serving on Tertiary Education Institution Councils. This is consistent with the reforms in governance inaugurated a decade ago under the Labour Government, but takes the process several steps further. The reduction in the total number of members on Councils (from 12-20 to 7-12) is premised on the assumption that smaller governing bodies will be "more efficient and clearly focused while still enabling the workload ... to be adequately spread among members" (Ministry of Education, 1998, p. 39). No evidence is cited in support of this view. The arguments in favour of changing the composition of Councils are based on equally dubious and ambiguous claims. Academics, we are told, will continue to have "an essential role" given their knowledge of the "core educational and research functions" of tertiary education institutions (p. 39), yet with so few represented on Councils their views could easily become swamped by other concerns. The balance is heavily weighted in favour of "skills, knowledge, and experience" drawn from the commercial world. Council members will be required to make decisions based entirely on their judgements of "the short- and long-term best interests of the institution" (p. 38), but it is not at all clear how "best interests" will be defined. Ensuring the financial viability of the institution is certainly a part of this, but apart from vague references to "accountability", other demands remain ambiguous. The call for greater accountability in the tertiary sector, repeated several times throughout the document, is based in part on unsubstantiated statements about Council members putting their own interests ahead of the overall good of their institutions under representational systems of governance (pp. 4-5). The notion that accountability mechanisms need to be improved is allegedly "widespread" (p. 5), but no evidence is provided to support this claim. 
Nothing is said about who might be critical of current systems of governance and accountability and what interests they might be serving.

\section{Research funding}

The introduction of contestable research funding was not unexpected (see Roberts, 1999). Support for a form of contestable funding can be found in the work of some commentators (notably, Boston, 1997) who have offered sharp criticisms of other aspects of the tertiary education reform process. As the proposals in the White Paper stand, no indication of a reduced overall budget for research funding is given, but neither is this eliminated as a possibility. Several features of the proposed system are problematic from our point of view. First, the shift from an EFTS-based distribution of monies for research to a contestable system forces academics to negotiate new layers of bureaucracy in seeking support for their work. More time will be spent completing application forms and less time will be spent actually doing research. Second, and of perhaps greater concern, academics lose (even more) control over the nature of their research activities and the focus of their scholarly inquiries. An EFTS-based system grants institutions considerable autonomy in determining research priorities (within a limited budget); with the progressive removal of funds into a contestable pool, control shifts squarely into the hands of government officials. This might be less objectionable if researchers could be confident the total pool of funds would increase (or at least stay at current levels, after adjustments for inflation), and provided all domains of research activity would be eligible for funding. It is clear from the White Paper, however, that some areas of research will be more likely to attract funds than others. The contestable fund will target "advanced, high-quality research portfolios with a strong strategic focus" (p. 32). Applications will be assessed on the following criteria:

- Demonstrated quality and capacity of researchers: Researchers bidding for this funding will need to submit recent track records of research activity in the area for which funding is sought. Judgements will be based on such factors as recognised publications and the local, national, and international significance of past research (where relevant);

- Quality of the proposed research portfolio: This quality will be judged on the basis of the design and purpose of the proposed portfolio, its feasibility, the research methods, the skills and technologies to be developed and used, and the relationship to other programmes and investments.

- Strategic focus: Researchers will need to demonstrate how their portfolios will develop the innovation and human resource capabilities of New Zealand.

- Cost-effectiveness: All elements of proposed research portfolios will need to be appropriately costed. (pp. 32-33)

Few researchers would object to the idea that research should be of "high quality" if it is to receive funding. Many, however, would want to debate questions about how "quality" is to be determined. In universities, the "acid test" of quality has long been international peer review. The White Paper places this convention under threat, transferring control over criteria for quality to Government officials. This is ostensibly because accountability arrangements for the use of EFTS-based funds "have not been strong" (p. 28). As with other claims about accountability in the document, this remains merely an assertion, with no argument or evidence mustered to support it. Several groups of researchers will be disadvantaged under the new system. Those just beginning their academic careers will find it difficult to compete against experienced researchers with lengthy funding and publications records. Those with interests and expertise falling outside the "strategic" criteria specified in the White Paper will find little or no support. Finally, those whose research depends more on time than money will find themselves short of the former precisely because they will not gain the latter.

The implications of the new system are far-reaching. A small group of experienced researchers in selected strategic areas (particularly those with quantifiable and readily discernible economic benefits) will do well under the new system, and might expect to gain both funding and the necessary time, space and resources to do their work. Others will become "outcasts" in the new order. They may continue to hold academic posts if their courses meet "student needs" (current enrolment preferences), but they will be required to undertake more teaching and administration, with little or no time for research. This is made explicit in the stipulation, foreshadowed by the Tertiary Education Review Green Paper, that teachers of undergraduate degree courses do not need to be active in research (that is, "research" as it has traditionally been defined in universities). For the early years of undergraduate study at least, "research can reflect a personal involvement by the 
teacher characterised by the continual refreshing of the mind through the updating, investigation, and scholarship in the given discipline" (p. 29). For the moment, a largely arbitrary line is drawn between undergraduate and (post)graduate teaching; in the future, the loosening up of the concept of research might apply at higher levels as well. This would produce what might in the past have been called "teaching" (as opposed to "research") institutions, many of which might still want to claim the name "university", while simultaneously reducing the perceived obligation on the part of the Government to provide support with research funding. Some domains of inquiry will be considered "irrelevant" in a system driven by student demands and economic imperatives, and entire fields of study could disappear from New Zealand tertiary education curricula.

\section{Qualifications reform}

Elsewhere (Roberts, 1997) it has been noted that the NZQA was in a tenuous position given its heavily bureaucratic structure and growing unpopularity among members of the university, polytechnic and secondary school communities. In the White Paper we see the "thinning" of the NZQA, with many of its former functions to be taken over by the new Quality Assurance Authority of New Zealand. While the new body spreads the load of quality-control responsibilities, it also adds another layer to the bureaucracy. Whether this will have the effect of "streamlining" the qualifications reform process, or making it more cumbersome, remains to be seen. In an unusually forthright letter to the New Zealand Education Review, David Hood (1999, p. 6), former Chief Executive of the NZQA, offers some strong criticisms of the proposed changes. He sees the NZQA as being "demoted" under the new system. The Government, he believes, has caved in to vocal protests about unit standards from those who purport to speak for the universities and polytechnics. In his view, the National Qualifications Framework and the associated Skill New Zealand strategy have been "highly successful". Indeed, he goes as far as to suggest that the NZQA has perhaps been too successful, and is now being "punished" for challenging "the conventional and traditional". Critics, he says, have tended to attack unit standards from a theoretical or technical point of view, when in practice they work well. Much of what is in the White Paper will, Hood maintains, take New Zealand on a "giant leap backwards". Hood favours a "flexible" ("shopping basket") approach to the acquisition of tertiary qualifications, whereas the White Paper wants to "return to qualifications as the end point of a fixed length, seemingly because it fits more readily to a particular funding model".

Hood's letter is all the more remarkable given his previous position as a senior official and his firm support for a market model of education. To us, Hood's similarities with those he criticises in the Government are far greater than his differences with them. His letter is replete with the language of neoliberalism. He describes students as "consumers" and the "primary customers" of tertiary education. In discussing why the NZQA was established, he speaks (approvingly) of the opening up of the education "market" to private training establishments, the shift in emphasis "from inputs to outcomes", and the "flexible provision" of educational programmes. Hood seems to us to have placed undue emphasis on one element of the restructuring process proposed by the White Paper while downplaying other elements highly compatible with the vision he had for the NZQA. A reduction in the regulatory authority of the NZQA has long been a possibility and was predicted nearly two years ago (Roberts, 1997), but while the new structure may appear to Hood as a reaction to noisy detractors in two tertiary interest groups it is unlikely to provide much comfort for such critics. For, as has been argued at greater length elsewhere (Roberts, 1996), the target of university criticisms - from individual academics, the New Zealand Vice-Chancellors' Committee, and the Association of University Staff of the NZQA reform process was never simply unit standards. Rather, the concern, at a deeper level, was with the technocratic and managerialist assumptions underpinning unit standards, among other features of the NZQA reform process. It is the very conceptions and practices of education flowing from the sort of language Hood employs in his letter that many university critics object to. The White Paper may allow universities to side-step unit standards, a concession signalled in the 1997 Green Paper on qualifications policy (Ministry of Education, 1997c), but the broader ideological and political parameters within which quality assurance processes will have to operate remain the same.

\section{Academic freedom}

We turn finally to the question of academic freedom under the new system. Here we want to join John Codd (1998) in arguing that this is perhaps the most worrying feature of the White Paper. Under the indicative legislation detailed in the third appendix to the document, the Minister of Education is granted unprecedented new powers in the governance of tertiary education institutions. The Minister must appoint 
the first Council of new tertiary education institutions (section 165A). Every Council will be "accountable to the Minister for the efficient and effective governance of the institution, including the discharge of its statutory functions, and for the educational and financial performance of the institution" (181A). Proposed amendments to Council charters can only be made with Ministerial approval (184/2). It is a requirement that charters specify the "goals and purposes of the institution", together with "[t]he number of members of the Council ... and the manner in which they are appointed, hold office, and may resign or be removed" (184/1). New powers of intervention go far beyond those extended to Ministers in the past. Sections 222B to 222L of the indicative legislation have been set up to allow the Minister of Education "to intervene in the operation of a tertiary education institution, where, in the opinion of the Minister, the effective operation of the tertiary education institution is at risk, in a manner that is appropriate to address the nature and severity of the risk" (222A, emphasis added). Under the new legislation, the Minister will have the power to appoint an observer to the Council of a tertiary education institution (222D), and direct a Council to take "independent" advice (222E) or prepare an action plan (222G). The Minister will be able to appoint members to a Council (222F/1), subsequently terminate those appointments $(222 \mathrm{~F} / 4)$, and even dissolve the entire Council. The Minister will have the right to appoint a Commissioner who will act in the place of a dissolved Council (222J). The reinstatement or replacement of a dissolved Council will also be at the discretion of the Minister (222L).

These extraordinary new powers constitute a direct and serious threat to both academic freedom and institutional autonomy. The authors of the White Paper draw a distinction between the two ideals, conceding that the new arrangements "may impinge on institutional autonomy" but claiming that "neither the governance nor the accountability arrangements will encroach on the principle of academic freedom" (p. 41). We disagree. In our view, the two principles are - or have been historically - linked, at least in theory. Exercising the "critic and conscience" role ascribed to universities demands a high degree of autonomy over substantive and procedural matters in the day-to-day running of an institution. This does not mean, of course, that institutions should be free from the scrutiny of those who provide some or all of their funds. But if a university is to discharge its responsibility of upholding rigorous standards of critical inquiry - which may include the investigation, teaching and discussion of controversial or un popular ideas - tight limits need to be placed on the circumstances under which, and the ways in which, the funding body might intervene in the affairs of the institution (cf. Boston, 1995). The new powers granted to the Minister under the indicative legislation place few limits on what might be considered necessary grounds for interference. There is little to prevent a Minister of Education, should he or she be so inclined, from appointing political allies or removing those known to hold contrary views to his or her own. There is an increased possibility of a government withdrawing support for programmes of study considered "too radical" or undesirable for some other (politically motivated) reason, given the new powers the Minister has over charters, judgements about the performance of the Council, and the appointment or termination of Council members. The new powers of intervention allow the other elements of the White Paper reform package to fall more neatly into place. Ensuring emphasis is placed on research and teaching in areas of "strategic" (economic)importance will be easier if the governing bodies of tertiary institutions are subject to all the avenues for possible interference noted above. The balance between the different functions of a tertiary education institution - research, teaching, administration, community activities, etc. - can be controlled with greater ease, given the composition of Councils and the Minister's powers of "correction" under the new system.

We would argue, as Codd does, that what is needed is neither a lack of accountability from institutions to the government (or students, or anyone else involved in tertiary education), nor a situation in which the government has extensive powers over matters of governance, but rather a buffering mechanism between the institution and the government. The University Grants Committee used to perform this role, as a body "independent of the government, while being accountable to it" (Codd, 1998, p. 11), but there are other means of ensuring the proper balance between accountability and autonomy is retained. Codd suggests a financial auditing unit attached to the New Zealand Vice Chancellors' Committee as one possibility; another might be an organisation comprising representatives from students' associations, academic staff organisations, university management, and various community groups. The motives for dispensing with the University Grants Committee a decade ago were primarily (but not exclusively) financial in nature; the current government, we suspect, would object to the idea of a buffering body on ideological grounds as well. The proposed new powers granted to the Minister under the 
indicative legislation show just how far the government is prepared to go to avoid such a possibility. Codd neatly captures what is at stake in the debates over governance and accountability:

It is self-evident that some (perhaps most) governments do not favour the provision of funds to support ideas, views, teachings or even research, that is contrary to their ideologies or policies. In a society that upholds liberal democratic values, however, the independence of its universities is essential to their purposes as "critic and conscience of society". That independence must be protected in legislation against the actions of a future government that may seek to control what is taught in universities and suppress the social criticism that arises within them. We need to be reminded often that the price of freedom is eternal vigilance (p. 11).

\section{Concluding Comments}

The battle lines over the future of New Zealand universities were drawn more than a decade ago with the publication of the Watts Report (Universities Review Committee, 1987) and the Treasury (1987) brief to the incoming Government. The Watts Report, commissioned by the New Zealand Vice-Chancellors' Committee, expressed broad support for the standard of university education in New Zealand, and argued for a substantial increase in state funding to encourage greater numbers of students into full-time study. No changes to existing systems of governance were suggested. The Treasury brief, by contrast, advanced a case for a reduction in state expenditure, an increase in "user" charges and an emphasis on "consumer" choice. As Boston (1988, p. 1) notes, both reports recommended special assistance for students from poorer backgrounds and advocated major reforms in university administration, staffing and remuneration. In the years following the release of these two reports, the Treasury vision has prevailed and the Watts Report has been largely forgotten or ignored. The policy proposals set out in the White Paper follow along the same path established by the 1987 Treasury brief, and will, over time, radically alter the face of tertiary education in New Zealand.

We see some positive features in the White Paper. For example, the notion of providing full and accurate information for students attempting to choose between institutions is difficult to argue against, though we would hasten to add that this is a necessary rather than sufficient condition for good decision-making. The choices we make, and the way we make them, may be heavily influenced by a host of experiences and encounters, including those we have in other educational settings (e.g., schools). Conversations with other students and/or staff members, family circumstances and expectations, and the "marketing" of educational programmes (e.g., via television advertisements) are also significant factors in shaping choices. The expressed goal of improving Maori participation rates in tertiary education is also admirable, as is the recognition that many Maori students may prefer to study in a wananga learning environment. Yet, the White Paper makes no firm commitment to Maori in terms of providing the necessary resources for the further development of wananga. Indeed, while many of the issues relating to the establishment of wananga are still "being considered" by the Government (p. 50), it seems clear that the variable subsidy regime will be insufficient to meet capital requirements for new institutions.

Overall, the White Paper provides disheartening reading for those committed to a comprehensive, properly-resourced public tertiary education system. The document lacks any sense of history; it conveys no commitment to, or critical engagement with, intellectual ideals developed over hundreds of years in universities and other institutions of higher learning such as the traditional whare wananga in Aotearoa. As in the Tertiary Education Review Green Paper, there is no thought given to the contribution the arts and the humanities might make to New Zealand society. The cultural dimensions of higher education are, save from brief comments on the distinctive role of wananga, ignored. The idea that tertiary education might serve ends other than those generated by self-interest is never taken seriously; the notion that tertiary study ought to be its own end, and that this alone might justify continued public investment in universities and other institutions, is even more foreign to the discourse of the White Paper. When the justifications for policy changes occasionally shift from the language of serving the so-called "needs" of individuals, the appeal is typically to some other goal consistent with neoliberal political philosophy (e.g., national economic competitiveness).

The early reference to "social cohesion" needs to be contextualised as part of the same neoliberal discourse. This term, which is not defined or explained in the White Paper, has found currency in marketised societies around the world. References to the term can be found as far back as the Hawke Report (Department of Education, 1988a), but in recent times it has become a "buzzword" for government officials, and has appeared in a number of recent New Zealand policy documents 
(e.g., the Foresight Project materials). We see the goal of "social cohesion" as the latest attempt by governments in neoliberal societies to secure the "social bond" (Lyotard, 1993): to bind citizens to the prevailing economic and philosophical doctrine of neoliberalism. The adhesive in this case is competitive individualism, and the citizens who cohere have been reconstructed as "consumers". Promoting "social cohesion" demands the denial of difference, the containing of criticism within pre-defined parameters, and the suppression of alternatives to market liberalism. After more than a decade of breaking communities down, right-wing politicians are now - through appeals to social cohesion or the closely-related term, "social capital" - attempting to bring them back together again. (Former Prime Minister Jim Bolger was one of the most prominent proponents of such a synthesis near the end of his parliamentary career.) This involves a reconfiguration of the notion of community: the replacement of an ethic of collective care with the apparently paradoxicalidea of people being bound together by their commitment to serving their own individual (competitive and economic) interests.

The fate of the White Paper over the next few years will, to some extent, be determined by the results of the next general election. The two major opposition parties, Labour and the Alliance, differ somewhat in the detail of their a pproaches to tertiary education policy but both are committed to maintaining a credible public system. Steve Maharey, Labour Associate Education (Tertiary) Spokesperson, has this to say about the White Paper: "It is now 'crunch time' as the White Paper proposals would destroy New Zealand universities to such an extent that academics world-wide would no longer recognise them as peer institutions" (Association of University Staff of New Zealand, 1998, p. 4). Labour sees the new system of research funding introduced in the White Paper as "punitive" and opposes tertiary capital charging. Alliance Education Spokesperson Liz Gordon has argued that the competitive behaviour encouraged under the new student funding system would lower standards and further weaken the international standing of New Zealand universities. The "sinking lid" policy applied to universities could no longer be sustained (Association of University Staff of New Zealand, 1998, p. 3). The path from policy to practice also rests in the hands of voters, for whom tertiary education has become an increasingly important issue in recent years. There has been extensive publicity in the popular media over the past year about growing levels of student debt. The injustice of one generously supported generation making the next pay heavily for taking up the same opportunities in tertiary education has not been lost on young people, their parents, and many members of the wider voting community. The reduction in government support for tertiary education has been initiated by politicians who, for the most part, enjoyed the benefits of universal health care, higher welfare payments and comparatively low educational fees. In a world demanding perpetual (re)training, the momentous changes signalled in the White Paper will have a bearing on many New Zealand lives. Policy proposals of such significance warrant close critical scrutiny and ongoing debate.

Notes

1. A version of this paper is to be published in our forthcoming book, University futures and the politics of reform (Peters \& Roberts, 1999).

2. See, for example, Peters \& Roberts (1998a); Roberts (1999). (Both of these articles were accepted for publication prior to the release of the White Paper.)

\section{References}

Association of University Staff of New Zealand. (1998, December). Bulletin.

Boston, J. (1988). The future of New Zealand universities: An exploration of some of the issues raised by the reports of the Watts Committee and the Treasury. Wellington: Victoria University Press, for the Institute of Policy Studies.

Boston, J. (1995). The university as critic and conscience of society. In Combined Chaplaincies at Victoria University of Wellington (Eds.), The university, ethics and society - Tertiary Christian studies (pp. 143-151). Wellington: Victoria University of Wellington.

Boston, J. (1997, October 23). The tertiary education review: Issues and implications. Paper prepared for a staff seminar at the University of Auckland.

Codd, J. (1998, December 2). The price of freedom. New Zealand Education Review, p. 11.

Creech, W. (1998). Foreword by the Minister of Education. In Ministry of Education, Tertiary education in New Zealand: Policy directions for the 21st century (White Paper). Wellington: Ministry of Education.

Crozier, R. (1998). Foreword. In M. Peters \& P. Roberts (Eds.), Virtual technologies and tertiary education (pp. 9-14). Palmerston North: Dunmore Press. 
Department of Education. (1988). Report of the working group on post-compulsory education and training (Hawke Report). Wellington: Department of Education.

Hood, D. (1999, January 15). NZQA demotion. New Zealand Education Review, p. 6.

Kelsey, J. (1998, December 3). White Paper on education shows muddled thinking rather than vision. New Zealand Herald, p. A19.

Lyotard, J.-F. (1993). Political writings (B. Readings \& P. Griemas, Trans., B. Readings, Ed.). Minneapolis: University of Minnesota Press.

Ministry of Education. (1997a). A future tertiary education policy for New Zealand: Tertiary education review (Green Paper). Wellington: Ministry of Education. < http://www.minedu.govt.nz/data/NQF/paper/htm>

Ministry of Education. (1997b). Tertiary education review: Proposals and key decisions. Wellington. (Draft document dated July 17, 1997, leaked to the media.)

Ministry of Education. (1997c). A future qualifications policy for New Zealand (Green Paper). Wellington: Ministry of Education. $<$ http://www.minedu.govt.nz/data/NQF/paper/htm $>$

Ministry of Education. (1998). Tertiary education in New Zealand: Policy directions for the 21st century (White Paper). Wellington: Ministry of Education.

Ministry of Research, Science and Technology. (1998). Building tomorrow's success: Guidelines for thinking beyond today. (The Foresight Project). Wellington: MoRST. $<$ http://www.morst.govt.nz/foresight/front.html>

Peters, M., \& Roberts, P. (1998a). Agendas for change: Universities in the 21st century. New Zealand Annual Review of Education, 7, 5-28.

Peters, M., \& Roberts, P. (Eds.). (1998b). Virtual technologies and tertiary education. Palmerston North: Dunmore Press.

Peters, M., \& Roberts, P. (1999). University futures and the politics of reform. Palmerston North: Dunmore Press.

Roberts, P. (1996). Structure, direction and rigour in liberating education. Oxford Review of Education, 22(3), 295-316.

Roberts, P. (1997). Qualifications policies and the marketisation of education: A critical reading of the Green Paper. Access: Critical Perspectives on Cultural and Policy Studies in Education, 16(2), 31-47.

Roberts, P. (1999). The future of the university: Reflections from New Zealand. International Review of Education, 45(1), 65-85.
The Treasury. (1987). Government management: Brief to the incoming government, vol II: Education issues. Wellington: Government Printer. Universities Review Committee. (1987). New Zealand's universities: Partners in national development. (Watts Report). Wellington: New Zealand Vice-Chancellors' Committee.

\section{The authors}

Peter Roberts and Michael Peters, both of the School of Education at the University of Auckland, share research interests in educational philosophy and critical policy studies. They have published in a wide range of international journals. Their books include Virtual Technologies and Tertiary Education (Peters \& Roberts, 1998b), and University Futures and the Politics of Reform (Peters \& Roberts, 1999). 